\title{
The Extrinsic Goals and The Meaning of Money for Student Who Has Career Profession Preference at Hasanuddin University
}

\author{
Nurul Aisyah \\ Department of Psychology \\ Hasanuddin University \\ Makassar, \\ Indonesianeah0111@gmail.com
}

\author{
Muhammad Tamar \\ Department of Psychology \\ Hasanuddin University \\ Makassar, Indonesia \\ tamarpsikologiuh@gmail.com
}

\author{
Sri Wahyuni \\ Department of Psychology \\ Hasanuddin University \\ Makassar, Indonesia \\ uniena_84@yahoo.co.id
}

\begin{abstract}
This research is a correlation study aimed to determine the relationship between extrinsic goals with the meaning of money on students who have a career preference in the field of professional in Hasanuddin University. Subjects in this study were 132 students who took the professional program at the Hasanuddin University. This study used two scales have been modified as a measuring tool, namely Money Ethics Scale (MES) consisting of 36 items and extrinsic goals sub-scale of Aspiration Index, consisting of $\mathbf{4 5}$ items. This research analyzes used Product Moment Correlation. Based on the analysis found that there is a positive relationship between extrinsic goals with the meaning of money on students who have a career preference profession at Hasanuddin University, with raw score is 0.388 and a significance value is 0.000 . It means that the higher the extrinsic goals of students who have career preference professions meaning the money will be higher.
\end{abstract}

Keywords-extrinsic goals; meaning of money; career

\section{INTRODUCTION}

A profession is a job or occupation that demands a high level of intellectual expertise and an independent ethical responsibility in practice. Understanding Profession by Good, et al. [1] in the Dictionary of Education defines the profession as a job requiring the preparation of a relatively long specialization in the College and controlled by a special code of ethics. Before working in the field of professionalism, individuals first through education in universities to achieve the capabilities and legality in the field of profession. Therefore, individual guidance during a student is considered important for the preparation to face the possibilities that will be faced when engaged in the field of professionalism.

In choosing a profession, it is closely related to motivation [2]. This theory states that the forces that motivate a person to work in a particular profession depend on the mutual relationship between what is desired and needed from the work. This applies also to practitioners. Motivation can be influenced by internal factors and external factors. From the symptoms that have been presented, researchers see the tendency of life goals in the form of financial success. Financial success is a desire that leads to the achievement of material success [3]. When viewed in the concept of agoal content proposed by [4], financial success (financial success) is one of three extrinsic goals, two of which are attractive appearance and social recognize.

A person who has a goal content in the form of financial success is likely to exhibit behavior in material-oriented work. Money-based rewards are considered a powerful motivational driver [5]. Other studies have shown that extrinsic factors are often detrimental to desired work attitudes and outcomes (eg, creativity, cognitive flexibility, and problem solving [6].

Money earns value as a perceived result to access other desired results [7]. The meaning of money depends on the individual, but money itself is a meaningful goal to acquire goods and meet the needs and the desires that are indispensable and affect some aspects of modern life. Tang [8] indicates that social values are related to money matters and argue that in a materialistic society, people are driven by money and see money as a resource and happiness. The hypothesis in this research is that there is a relationship of extrinsic goals with the meaning of money on students who have career preference profession field at Hasanuddin University.

\section{METHOD}

This research is a correlational research. Characteristics of subjects in this study include students of study programs that have a professional education at Hasanuddin University and have career preference in the field of profession. Subjects in this study were 132 students of professional programs at Hasanuddin University, consisting of 64 Students of Professional Pharmacist Education Program and 68 Students of Master Program of Notary. The subjects were chosen using purposive sampling technique. 
The meaning of money is measured using a measuring instrument known as Money Ethics Scale (MES) developed by Tang and his Colleagues [8][9][10]. In addition, the Aspiration Index developed by Ryan and Kasser measures extrinsic goal [11]. This scale consists of 105 items from 3 subscales namely extrinsic goals (financial success, attractive appearance, and social recognition), intrinsic goals (self acceptance, affiliation, community feeling) and health. However, the scale used in this study is the extrinsic goals subscale. The data obtained were analyzed using Product Moment correlation analysis.

\section{RESULT}

Descriptive statistics of data obtained in this study indicate that the mean value of the meaning of money 58.23 and the mean value of extrinsic goals of 69.71. The standard deviation of meaning of money in this study amounted to 10.48 and standard deviation of extrinsic goals of 17.89 with the number of subjects as many as 132 subjects.

Based on the results of statistical tests, obtained $r=0.388$ with a value of 0.000 significance for the correlation between extrinsic goals with the meaning of money on students who have career preference profession field at Hasanuddin University. This shows that the null hypothesis (H0) is rejected and the alternative hypothesis (H1) is accepted which means there is a positive correlation between extrinsic goals and the meaning of money on the students who have career preference profession field at Hasanuddin University, where the higher the students' Will also be higher and vice versa, the lower the extrinsic goals then the meaning of the money will be lower.

In addition to the above results, additional aural results are also obtained. Additional analysis was performed using an independent sample t-test. This test is aimed to know the difference of two variables. If the value of significance obtained is greater than 0.05 , then it can be said that there is no difference between the two variables. The results obtained as follows:

1) The meaning of money is reviewed by sex differences Subjects of male have mean value of meaning greater money (58.71) than in women (57.98). There is no significant difference in the meaning of money (0.216> 0.05 ) between the male and female subjects.

2) The extrinsic goals are reviewed by sex differences

Male subjects had a greater mean value of extrinsic goals (73.55) than women (70.62). There is no significant difference in the meaning of money $(0.503>0.05)$ between the male and female subjects.

3) The difference in the meaning of money is reviewed based on the study program

The subject of the pharmacist study program has a mean value of smaller money (57.11) than the subject of the study program (59.22). There is no significant difference in meaning of money $(0.779>0.05)$ between the subject of the pharmacist study program and the notary study program.

4) Differences in extrinsic goals are reviewed based on the study program
The subject of the pharmacist study program has a mean value of smaller extrinsic goals (69.57) than the subject of the notary course (69.84). There is no significant difference in the meaning of money $(0.729>0.05)$ between the subject of the pharmacist study program and the notary study program.

\section{DISCUSSION}

The results of this study indicate that there is a positive relationship between extrinsic goals and the meaning of money on students who have career preference profession field at Hasanuddin University. This means the higher the students' extrinsic goals, the meaning of student money will also be higher and vice versa, the lower the extrinsic goals the meaning of the money will be lower. The value of correlation significance between these two variables is 0.388 that means that the correlation values of both variables are in low category. This means that not always extrinsic high goals will show a high meaning of money as well, vice versa.

The results of this study are supported by research conducted Duriez et al. suggests that individuals who have extrinsic goals are highly concentrated on money and status [12]. In addition, Tang also revealed that money-based rewards are considered as a powerful motivational trigger [5]. Thus, it can be said that the behavior of individuals can reflect how personal goals and how individuals are in the meaning of money. A person's goals reflect personal pursuits, personal plans, what are the present goals and life tasks. Someone who has goal content in the form of extrinsic goals will tend to show behavior in work oriented in the material.

In this study also shows that the interpretation of subject money tend to be in the medium category, which is about $39 \%$ or about 52 subjects. This amount is at most compared to the low category, which amounts to about $30 \%$ or 39 subjects, and high category which amounts to about $31 \%$ or 41 subjects. The level of meaning of this money can change and potentially become higher. This is because the subject in this study is a student and has not been involved as a professional workforce. This opinion is supported by research conducted by Tang and Luna Arocas indicating that individuals who are already working show a higher level of meaning of money [13]. This is because individuals who are already working more aware of the importance of needs and how to meet the needs in life.

Based on sex differences, there is no difference in the meaning of money. This result is different from the research done by Tang et al. who examined the relationship between the levels of meaning of money assessed by the satisfaction of income revenues by sex [14]. The results show that men are more satisfied in terms of finances than women are. Men feel satisfied because they tend to have higher income, while women feel less satisfied because they earn less income than men. Women feel financially poor because they tend to earn low income, have financial problems and are more obsessed with money than men. This shows that the higher level of meaning of money is more in women than men.

Another variable in this study is extrinsic goals. Extrinsic goals of the subjects in this study, more dominant in the 
medium category is about $36 \%$. This amount is more than the number in the low category of $32 \%$ and high category, which amounted to $33 \%$. In addition, the results of this study indicate that there is no difference in extrinsic goals by sex differences.

The results found are different from those proposed by Midgley which suggests that men are more likely to possess extrinsic orientation than women [15]. The discrepancy in the results of extrinsic goals by sex from this study with prior research may be due to cultural differences. Where one of the factors that may affect the individual's extrinsic goals is culture [15] [16]. Individual Goals come from nature and culture. Among the individual goals, reflect the peculiarities of a particular economic system. This economic system plays an important role in regulating behavior and experience in everyday life and is thought to affect the individual's goal content [16]. In addition, collectivist culture and individualistic cultures are thought to have an effect on the extrinsic goals [16]. Individualistic culture assumes that extrinsic goals in this respect are financially, attractiveness and fame as the description of individual success.

Indonesian society as part of Eastern society is assumed as collectivist society. The collectivist society is a society of interdependence, self-criticism and hard work for selfimprovement, self-discipline in the form of diligent endeavor and withstand full self-control testing in order to improve interdependence with in groups, emphasis on skeletons External reference or reliance on social environmental assessment, emphasizing shame and apology, and emphasizing control and emotional balance [17]. Therefore, collectivist societies follow more and pay attention to social rules about how men and how women should become. However, in a study conducted by Supratiknya found a strong indication that both within the Indonesian community, subjects tend to begin to loosen themselves from traditional ties, especially from traditional sex-typing tendencies that draw a firm line between male and female [18]. Therefore, it can be said that the tendency of Indonesian society to loosen themselves from the traditional sex-typing effect on the absence of male and female differences in the meaning of money and determine the extrinsic goals.

If reviewed on the study program, additional analysis results are obtained that there is no difference in the interpretation of money based on professional programs and no differences in extrinsic goals are reviewed based on professional programs. This may be due to the two subject groups being professional program students, where the professional workforce is a community-oriented workforce, a code of ethics of professionalism, high public trust and high social status compared to other positions [19]. Therefore, there is no difference between the meaning of money and extrinsic goals on the students of professional programs of pharmacists and students of notary profession programs at Hasanuddin University.

\section{CONCLUSION}

The conclusion of this study are:

1) There is a positive relationship between extrinsic goals and the meaning of money on students who have career preference profession field at Hasanuddin University. This means the higher the students' extrinsic goals; the meaning of student money will also be higher and vice versa, the lower the extrinsic goals the meaning of the money will be lower. The level of correlation between these two variables is in the low category. This means that not always the extrinsic goals high indicate high money consumption, and vice versa.

2) There is no difference in the meaning of money and extrinsic goals are reviewed by sex differences.

3) There is no difference in the meaning of money and extrinsic goals are reviewed based on professional study program.

\section{REFERENCES}

[1] C.V. Good. Dictionary of education. Vol. 553. New York: McGrawHill, 1959.

[2] A.S. Chan. "Analisis Faktor-Faktor Yang Mempengaruhi Pemilihan Karir Menjadi Akuntan Publik Oleh Mahasiswa Jurusan Akuntansi”.. Jurnal ilmiah mahasiswa akuntansi, vol.1, no.1, Jan. 2012

[3] T. Kasser and A. Ahuvia. "Materialistic values and well-being in business students." European Journal of Social Psychology, vol. 32, pp. 137-146, 2002

[4] R.M Ryan, K.M. Sheldon, T, Kasser, and E.L. Deci. All goals are not created equal: An organismic perspective on the nature of goals and their regulation, 1996.

[5] T. Tang, T., A. Furnham., and G. Mei-Tzu Wu Davis. "Money, The Meaning On Money, Management, Spirituality And Religion". Journal Of Management, Spirituality And Religion, vol. 7, pp. 173-189. 2010.

[6] B. J. Dik, A. M. Sargent, and M. F Steger. "Career development strivings assessing goals and motivation in career decision-making and planning". Journal of Career Development, vol. 35, pp. 23-41. 2008.

[7] T. Tang, A. Furnham, and G. Mei-Tzu Wu Davis. "Income and quality of life". Journal of Business Ethics, vol. 72, pp. 375-393. 2010.

[8] T.L.P Tang. "The meaning of money revisited." Journal of Organizational Behavior, vol. 13, pp.197-202, 1992

[9] T.L.P. Tang. "The meaning of money: extension and exploration of the money ethic scale in a sample of university students in Taiwan." Journal of Organizational Behavior, vol.14, pp. 93-99, 1993

[10] T.L.P Tang. "The development of a short money ethic scale: Attitudes toward money and pay satisfaction revisited." Personality and Individual Differences, vol. 19, pp. 809-816, 1995

[11] T. Kasser, and R. M. Ryan. "Further examining the American dream: Differential correlates of intrinsic and extrinsic goals." Personality and Social Psychology Bulletin, vol.22, pp. 280-287, 1996,

[12] B. Duriez, J. Meeus, and M. Vansteenkiste. "Why are some people more susceptible to ingroup threat than others? The importance of a relative extrinsic to intrinsic value orientation". Journal of Research in Personality, vol. 46, pp. 164-172, Jan. 2013.

[13] T. L.P. Tang, T. Sutarso, A. Akande, M. W. Allen, A. S. Alzubaidi, M. A. Ansari, and B. S. Cheng. "The love of money and pay level satisfaction: Measurement and functional equivalence in 29 geopolitical entities around the world". Management and Organization Review, vol. 2, pp. 423-452. 2006.

[14] R .Tang, R. T. Luna-Arocas, and Sutarso. "From income to pay satisfaction: the love of money and pay equity comparison as mediators and cultu-re (the United States and Spain) and gender as moderators". The Journal of the Iberoamerican Academy of Management, vol. 3, pp. 7-26. 2005.

[15] C. Midgley. (Ed.). (2014). Goals, goal structures, and patterns of adaptive learning. Routledge. 
[16] R. M. Ryan, V. I. Chirkov, T. D. Little, K. M. Sheldon, E. Timoshina, and E. L. Deci, E. L. (1999). "The American dream in Russia: Extrinsic aspirations and well-being in two cultures". Personality and social psychology bulletin, vo. 25, pp. 1509-1524. 1999.

[17] S. J. Heine, D. R. Lehman, H. R. Markus, and S. Kitayama. "Is there a universal need for positive self-regard?". Psychological review, vol. 106, pp. 766. 1999.

[18] A. Supratiknya. "Konstrual-diri di Kalangan Mahasiswa". Jurnal INSAN, vol. 8, Agustus. 2006.

[19] G. Sukmaningtyas, G. "Sikap Dan Ekspektasi Mahasiswa Non Kependidikan Program Profesi Keguruan Ikip Pgri Semarang Terhadap Profesi Guru.” Disertasi, Universitas Negeri Semarang, 2010. 